\title{
Mezi Prahou a Bruselem: nevládní organizace, sociální hnutí a zájmové skupiny na cestě do EU
}

\author{
Ondřej Císař
}

\section{Úvod}

Česko vstoupilo do Evropské unie (EU). Co to bude pro Českou republiku (ČR) znamenat? Obecně lze předpokládat, že (analogicky k situaci v těch státech, které se staly součástí EU dříve) členství v EU přinese ČR řadu změn. V důsledku adaptačního tlaku evropských institucí můžeme očekávat, že se v mnoha oblastech politické sféry promění způsob chápání, formulace a řešení problémů. Jinými slovy řečeno, řada formálních i neformálních pravidel a norem, procedur, sdílených významů a politik prodělá díky členství v EU a s tím spojeným dopadem europeanizace (europeanization) významnou transformaci (srov. Cowles, Caporaso, Risse 2001, zvláště pak Risse, Cowles, Caporaso 2001 a Cowles, Risse 2001).

Europeanizací se zde myslí efekty členství v EU na domácí politiky, politický proces a institucionální strukturu, tj. efekty členství na policies, politics a polities členských států (k trojdimenzionálnímu pojetí politiky viz Fiala, Schubert 2000: 17-19). Podle Franka Schimmelfenniga se proto studium europeanizace zabývá „dopadem politických výstupů a institucí na evropské úrovni na domácí politické instituce (polities), politický proces (politics) a politiky (policies)“ (Schimmelfennig 2002: 4). Dodejme jen, že EU vyvíjela na přistupující země velmi výrazný vliv již $\mathrm{v}$ rámci přístupového procesu $-\mathrm{v}$ tomto případě tedy pojem europeanizace neoznačoval efekty členství, ale efekty podmínek členství, které tyto země musely splnit před svým vstupem do EU (srov. Linden 2002, Grabbe 2001, 2002, Císař 2003a, Dürr, Marek, Šaradín 2004, Königová 2004).

Studium politických efekti̊ členství v EU se tak může zaměřit na tři analyticky odlišitelné dimenze pojmu politika. Lze studovat projevy europeanizace v jednotlivých politikách (policies) členských států (např. jakým způsobem se členství v EU projevilo v politice ochrany životního prostředí). Dále lze studovat, jakým zpo̊sobem se proměny politik projevily v institucionální struktuře (polity) členských států (např. jaké byly v důsledku adaptačního tlaku EU vytvořeny nové instituce a přijaty zákonné normy, které proměnily konfiguraci politického pole daného státu). Stejně tak můžeme studovat projevy členství v interakcích politických

Sociální studia. Fakulta sociálních studií Masarykovy univerzity v Brně, 1/2004. S. 109-120. ISSN 1212-265X.

Tato studie vznikla s podporou výzkumného záměru MŠM 142300002 „Mládež, děti a rodina“. 
aktérů daného státu (politics). V tomto případě se ptáme, zda-li členství v EU vede k europeanizaci aktivit a strategií původně národních politických aktérů. To je otázka, kterou si primárně klade tento text. Přinese členství ČR v EU domácím politickým aktérům (nevládním organizacím, sociálním hnutím a zájmovým skupinám) nové př́ležitosti k tomu, aby bud' přesunuli své aktivity především na evropskou úroveň, nebo aby využívali více než dosud k dosahování svých domácích cílů zdrojů poskytovaných z evropské politické arény?

Vzhledem k tomu, že ČR vstoupila do EU právě v tomto roce, není možné na vznesenou otázku odpovědět na základě empirických dat. Ta zatím nejsou k dispozici. S využitím dostupných výsledků výzkumu v západoevropských zemích je však možné dopad vstupu do EU na politické interakce v ČR fundovaně odhadnout. Navíc je možné navrhnout koherentní teoretický rámec pro studium interakcí mezi EU a domácími (českými) politickými aktéry a takto formulovat výzkumnou agendu pro empirické studie, které se na tento problém zaměří $\mathrm{v}$ budoucnosti.

Tato studie je organizována následujícím způsobem. V první sekci budou stručně shrnuty některé závěry studia dopadu mezinárodní institucionalizace na aktivity a strategie nestátních politických aktérů. Druhá sekce propojí závěry předchozí sekce s konkrétní situací EU a jejích členských států. Tato sekce bude formulovat hypotézu textu: vstup nových zemí do EU by měl vytvořit pro politické aktéry v těchto zemích příležitosti pro transnacionální (evropské) jednání. Vstup do EU by se tedy měl krýt s rostoucí europeanizací aktivit a strategií původně národně zapuštěných nevládních organizací, sociálních hnutí a zájmových skupin. Třetí sekce představí na základě výsledků výzkumu europeanizace aktivit sociálních hnutí, některých zájmových skupin a nevládních organizací do značné míry skeptický pohled na proces europeanizace aktivit těchto aktérů. „Silnou“ europeanizaci nelze očekávat. To však neznamená, že by vstup ČR neměl na strategie domácích aktérů žádný očekávaný dopad. Poslední sekce proto navrhuje rámec studia tohoto dopadu.

\section{Internacionalizace a transnacionální vazby politických aktérů}

Studium vlivu mezinárodní institucionalizace (budování mezinárodních institucí) se stalo během 90. let 20. století základním kamenem výzkumu transnacionálních aktivit a strategií původně národně zakotvených (domácích) politických aktérů (srov. Tarrow 1999, 2001a, 2002; Risse-Kappen 1995, Galtung 2000 a také Rosenau 1992, 1998, 1999, Keohane, Nye 2000, ke shrnutí výzkumu nestátních aktérů v kontextu evropské integrace viz Cowles 2003). $\mathrm{S}$ určitým zjednodušením lze říci, že cílem těchto studií bylo vysvětlit, do jaké míry vede rostoucí propojování politické činnosti (tj. internacionalizace) na nadnárodní úrovni k rostoucí nadnárodní aktivitě nestátních aktérů a do jaké míry přispívá tato jejich aktivita k další internacionalizaci (v případě EU: k europeanizaci). Podle těchto přístupů fungují mezinárodní organizace jako jakési „korálové útesy v oceánu globální anarchie“ (Tarrow 2002: 242), které poskytují nestátním politickým aktérům (sociálním hnutím, nevládním organizacím, zájmovým skupinám) př́ležitosti $\mathrm{k}$ tomu, aby se organizovali napříč státními hranicemi a dosahovali svých cílů na nadnárodní úrovni.

Např́iklad Sidney Tarrow (2002) při studiu vlivu mezinárodních organizací na transnacionální mobilizaci nestátních aktérů (především sociálních hnutí) aplikuje přistup založený na pozornosti věnované širšímu politickému prostředí - tzv. struktuře politických příležitos- 
tí. Koncept „struktury politických prŕležitostí“ popisuje institucionální uspořádání určitého politického společenství (obvykle národního státu, polity). Tento koncept pomáhá odpovědět na otázku, proč dochází k mobilizaci a organizaci sociálních hnutí (a jiných politických aktérů) v určitém časovém okamžiku. Zjednodušeně můžeme říci, že k mobilizaci dochází tehdy, když se struktura politických prŕležitostí otevírá a aktér tak může získat př́stup do politického systému. Ve své původní formulaci byla struktura politických př́íležitostí ztotožňována s institucemi národních států. Teprve později se začalo uvažovat o možnostech užití tohoto konceptu na úrovni nadnárodní, kde je operacionalizován především ve formě mezinárodních institucí (srov. také Tarrow 1998, Meyer 2003 a následující sekci). K rozvinutí transnacionální spolupráce tak může dojít jen tehdy, když jsou nestátním politickým aktérům poskytnuty přiležitosti ve formě mezinárodnich organizací a norem (v př́ípadě EU tedy poskytují takové př́ležitosti evropské instituce a normy).

Podle S. Tarrowa umožňuje tato konceptualizace vzniku transnacionálních vazeb přesně specifikovat mechanismy, kterými mezinárodní organizace k jejich vzniku přispívají. Těmito mechanismy jsou zprostředkování (brokerage), certifikace, modelování a institucionální přivlastnění. Tarrow tyto mechanismy použivá ke kauzálnímu vysvětlení efektů mezinárodni institucionalizace na konstituci transnacionálních sití politických aktérů. Zprostředkováním chápe vytváření vazeb mezi dř́ve nepropojenými domácími aktéry, jehož výsledkem je alespoň dočasná politická identita, která předtím neexistovala. Certifikace označuje uznání aktéra nebo aktérů určitou mezinárodní organizací (např. EU). Modelování popisuje přijetí normy, formy kolektivního jednání nebo organizační formy, která byla vyvinuta v určitém politickém kontextu, v kontextu jiném. Institucionálním přivlastněním pak Tarrow rozumí užití zdrojů nebo reputace mezinárodní organizace $\mathrm{k}$ tomu, aby sloužily s touto organizací propojeným transnacionálním aktérům (Tarrow 1999: 23, 2001b: 248-249).

Protože jsou to mezinárodní organizace, které poskytují místa, v nichž tyto mechanismy pracují, ,jsou těmi nejpravděpodobnějšími místy, v nichž mohou domácí skupiny, které mají nedostatek zdrojů, překonat překážky transnacionálního kolektivního jednání“" (Tarrow 1999: 23-24). Podle Tarrowa tak mezinárodní organizace ve vztahu k nestátním politickým aktérům vykazují jednu důležitou charakteristiku - ,legitimizují př́stup nestátních aktérů na úrovně politického rozhodování mimo národní stát" (tamtéž: 24). V těch oblastech, které na mezinárodní úrovni vykazují vysokou úroveň institucionalizace, lze proto očekávat transnacionální kooperaci a formování přeshraničních vazeb mezi původně lokálními politickými aktéry. $\mathrm{Na}$ tento fakt upozornili také ti teoretici mezinárodních vztahů, kteří původně státostředné zaměření disciplíny rozšířili o studium transnacionálních nátlakových sítí a sítí původně národních nevládních organizací a sociálních hnutí (Keck, Sikkink 1998, Risse, Ropp, Sikkink 1999; ke shrnutí této literatury viz Císař 2003c: 9-12).

\section{Institucionální struktura EU: nové politické př́ležitosti}

$\mathrm{Na}$ základě teze o vlivu mezinárodní institucionalizace na jednání sociálních hnutí, nevládních organizací a zájmových skupin lze generovat hypotézu o očekávaném dopadu vstupu nových zemí do EU. Vstupem do EU se tyto země stanou součástí vysoce institucionalizovaného mezinárodního prostoru, který by měl výrazně přispět $\mathrm{k}$ internacionalizaci (v tomto př́padě: europeanizaci) jednání domácích politických aktérů. Vstup do EU jednak 
vytváŕí nové př́ležitosti pro aktivní zapojení těchto aktérů do politické činnosti na evropské úrovni a jednak podřizuje domácí politické pole adaptivním tlakům z EU, které ve svém důsledku proměňují podmínky politického boje na národní úrovni. V tomto smyslu lze předpokládat, že vstup ČR do EU povede jak k europeanizaci aktivit domácích politických aktérů (tj. k jejich vstupu do evropské politické arény), tak k europeanizaci domácího politického pole (tj. k výraznému ovlivňování domácích politických interakcí činnostmi původně nečeských politických aktérů).

Podle těchto předpokladů představuje institucionální struktura EU (popis jejího budování viz Fiala, Pitrová 2003) novou strukturu politických přiležitostí pro nestátní aktéry doposud zachycené $v$ hranicích národních států, kteří díky vstupu do EU mohou začít přímo kooperovat s evropskými institucemi a partnery v jiných zemích a „obkročit“ tak národní politické reprezentace. Europeanizace zájmové politiky by pak vedla ke konstituci mnohoúrovňové struktury evropské politické organizace. Právě tato struktura byla v kontextu teorií evropské integrace analyzována $\mathrm{v}$ rámci teorie mnohoúrovňového vládnutí (multi-level governance), která dnes představuje jednu z hlavních alternativ ke státostředným př́ístupům k evropské integraci, především k liberálnímu intergovernmentalismu (LI) převládajícímu mezi těmito př́ístupy. ${ }^{1}$

Pro LI jsou národní vlády nejdůležitějšími aktéry mezinárodní politiky a jedinými ,,agregátory“ preferencí domácích politických aktérů (Moravcsik 1991, 1993, 1998). Státy nejsou jen ,agregátory“ preferencí, ale také základními analytickými jednotkami LI, který vidí mezinárodní kooperaci jako výsledek úsilí vlád maximalizovat svou kontrolu nad domácí politikou. K mezinárodní spolupráci tak může dojít jen tehdy, pokud jsou v důsledku rostoucí mezinárodní závislosti státům vnuceny náklady jinými státy. Tyto náklady pak LI označuje jako „negativní mezinárodní politické externality“ (negative international policy externalities), které mají být očekávanou mezinárodní spoluprací eliminovány nebo minimalizovány. V př́padě pozitivních externalit není kooperace pravděpodobná. Avšak mezinárodní kooperace by podle LI neměla být chápána jako výsledek mezistátní nebo mezivládní interakce, nebot' skutečně rozhodujícím faktorem je kalkulace nákladů a výnosů různými zájmovými skupinami v daném státě. Vládní pozice je totiž formulována v průběhu konfliktu zájmů uvnitř daného státu. Postavení vlády v domácím politickém konfliktu je pak rozhodující pro ochotu této vlády participovat na evropském integračním procesu.

Podle LI je institucionální struktura EU pro národní vlády akceptovatelná jen do té míry, do níž posiluje jejich moc v domácí politické aréně. Podle Moravcsika a v souladu s Putnamovou teorií „dvoustupňové hry“ (Putnam 1988) posilují skrze mezinárodní spolupráci národní vlády svou pozici na domácím politickém hřišti: „Národní vlády využívají evropských institucí jako součásti ,dvouúrovňové strategie s tím cílem, aby s větším úspěchem překonaly domácí opozici“ (Moravcsik 1993: 515). Zájmové skupiny a nestátni aktéři tak v LI hraji důležitou roli, avšak pouze $v$ rámci jednotlivých národních politických arén. Institucionální struktura, v níž se zájmové skupiny pohybují, je strukturou národních politických institucí. ${ }^{2}$ Evropská politika je pak exkluzivní záležitostí národních reprezentací jednotlivých evropských států.

Podle paradigmatu „mnohoúrovňového vládnutí“ (MÚV) však LI prezentuje neadekvátní pohled na EU (Marks 1993, Marks, Hooghe, Blank 1996, Hooghe, Marks 2001). Na rozdíl od intergovernmentalismu MÚV přistupuje $\mathrm{k}$ evropské integraci jako $\mathrm{k}$ procesu, $\mathrm{v}$ němž je politická autorita sdílena mezi několika úrovněmi organizace vlády. Národní vláda ztrácí 
své exkluzivní postavení nejdůležitějšího aktéra na evropské úrovni a do modelu jsou přidány subnárodní a nadnárodní úrovně vlády. V porovnání s intergovernmentalismem MÚV tvrdí, že evropské instituce mají relativní institucionální autonomii, což ve svém konečném důsledku znamená, že musejí být chápány jako aktéři, kteří v evropském politickém procesu hrají nezávislou roli. Podle MÚV ztrácí národní stát v EU kontrolu nad politickým procesem, a to i kvůli tomu, že jednotlivé úrovně vlády jsou vzájemně propojeny místo toho, aby byly do sebe „vloženy“. Striktní rozdělení mezi domácí a mezinárodní politikou je tak zrušeno. V neposlední řadě je to distinkce mezi státem jako institucí (polity) a politickými aktéry, kteří v daném institucionálním rámci interagují (politics), co tomuto př́stupu umožňuje sledovat zapojení nestátních politických aktérů v evropském politickém procesu a zároveň vliv evropských institucí na domácí politické aktéry.

Jak je však možné, že politici jsou ochotni vzdát se státní suverenity, když např́íklad podle intergovernmentalismu je to právě státní suverenita, která je politiky ceněna nejvýše? Podle MÚV není suverenita hlavním zájmem politické reprezentace volené jen na několik let. V politické úvaze politika nehraje státní suverenita úlohu tak významnou jako jiné bezprostřednější úkoly a požadavky. Ty pak mohou být často úspěšně řešeny právě delegací rozhodovací autority na nadnárodní úroveň. Taková delegace vyrůstá bud' ze snahy vyhnout se politické odpovědnosti, nebo z úsilí zabránit určitým zájmovým skupinám účastnit se rozhodovacího procesu. To je však něco, co by LI dokázal popsat a vysvětlit také. Základní rozdíl mezi oběma přístupy spočívá $\mathrm{v}$ tom, že na rozdíl od intergovernmentalismu oslabuje podle MÚV taková delegace státní (vládní) aktéry a umocňuje aktéry nevládní. Politický proces v EU je proto charakterizován vzájemným propojením národních, regionálních a nadnárodních institucí, které umožňují různým politickým aktérům na různých úrovních vzájemně interagovat a „obejít“ národní (státní) úroveň tak, jak to např́íklad ilustruje přímá spolupráce mezi různými zájmovými skupinami a evropskými institucemi.

Mnohoúrovňové politické zřízení (polity), které se podle proponentů MÚV formuje v podobě EU, pak poskytuje nové struktury politických př́iležitostí, které umožňují politické jednání i na jiné než národní úrovni. Analogicky k tomu, jak se v návaznosti na rozvoj moderního národního státu rozvinula národní sociální a politická hnutí, očekávají někteří autoři, že se rozvinou transnacionálni sociální a politická hnutí v odpovědi na vývoj evropské mnohoúrovňové polity. Gary Marks prezentuje tento argument společně s Doug McAdamem: ,[...] do té míry, do níž evropská integrace vede k nahrazení, nebo pravděpodobněji k úpadku významu národního státu jako exkluzivního umístění formální institucionalizované moci, můžeme očekávat doprovodné změny ve formách a dynamice aktivity sociálních hnutí“ (Marks, McAdam 1999: 97-98).

Tato perspektiva tak nespojuje struktury politických př́ležitostí s politickými institucemi partikulárního státu, ale vidí je jako mnohoúrovňový koncept. Politické příležitosti se neotevírají jen v souvislosti s vývojem situace v určité národní polity, ale také v politických společenstvích jiných a v souvislosti s proměnlivými podmínkami panujícími v mezinárodních organizacích. Marks a McAdam navíc podtrhují flexibilitu strategií sociálních hnutí, nevládních organizací a zájmových skupin. Strategie politických uskupení nejsou rigidní, ale přizpůsobují se proměnlivým podmínkám partikulárních politických arén. To ve svém di̊sledku vede k překonání konceptuálního rozdilu mezi různými typy politických aktérů (napřs. sociálními 
hnutími na jedné straně a zájmovými skupinami na straně druhé) (srov. také Burstein 1999). V závislosti na konfiguraci politických př́ležitostí totiž sociální hnutí jedná v některých kontextech jako zájmová skupina a naopak.

Marks a McAdam se tak nesnaží pouze upozornit na nově se otevírající příležitosti pro politické jednání na evropské úrovni, ale zdůrazňují fakt, že sociální hnutí v odpovědi na určitou konfiguraci politických př́ležitostí promění také formy svého jednání, tj. promění své strategie. Toto použití konceptu struktury politických příležitostí má doplnit jeho všeobecně rozšířené užití k vysvětlení toho, proč se hnutí mobilizovalo v daném časovém okamžiku a proč bylo či nebylo nakonec úspěšné při prosazování svých požadavků. Podle Markse a McAdama nerozhoduje způsob „otevření “ politických př́ležitostí jen o načasování hnutí a jeho potenciálním úspěchu, ale také o jeho vlastní formě. V této souvislosti pak nelze očekávat, že by transnacionální aktivity sociálních hnutí kopírovaly jejich domácí strategie, naopak - „evropské strategie“ sociálních hnutí odpovídají specifickým podmínkám politické činnosti na evropské úrovni, a proto místo demonstrací, blokád a okupačních stávek sociální hnutí „lobbují úředníky Komise, najímají konzultanty, aby psali vlivové zprávy (impact reports), koordinují mezi sebou politická memoranda (policy papers), instruují právníky, aby se věnovali př́ípadům před Evropským soudním dvorem, a pouze příležitostně organizují veřejné protesty před budovou Evropského parlamentu ve Štrasburku“ (Marks, McAdam 1999: 102).

Proč nelze na evropské úrovni očekávat masovou mobilizaci sociálních hnutí? Základní překážkou je vysoká nákladnost organizace protestu v Bruselu. Namísto dopravy množství protestujících na dané místo je lobbování aktivitou, která nevyžaduje masovou mobilizaci, ale vyrůstá z užití jiných zdrojů - informací, sociálního kapitálu a legitimace. Na rozdíl od protestu není lobbování „,teritoriálně zapuštěno.“ Druhým problémem pro organizaci evropského protestu je neexistence celoevropských identit a loajalit, které by mohly protestu poskytnout sociální zdroje. A v neposlední řadě je struktura politických příležitostí na evropské úrovni mnohem otevřenější konvenčnímu než nekonvenčnímu politickému jednání. Podle Markse a McAdama jsou všechny evropské instituce - s výjimkou Evropského parlamentu - zvláště neotevřené nekonvenčním formám prosazování zájmů, ke kterým se sociální hnutí často obracejí na národní úrovni (tamtéž: 104-108).

\section{Europeanizace a transnacionální vazby politických aktérů}

Na rozdíl od Markse a McAdama, kteří v institucích EU vidí politické příležitosti pro europeanizaci domácí zájmové politiky, zaujímá Sidney Tarrow skeptičtější postoj a spíše než na prŕiležitosti pro evropskou politiku domácích aktérů upozorňuje na její překážky a omezení. Těmi jsou především nedostatek či slabost sociálních sítí na evropské úrovni, neexistence evropské kolektivní identity a neexistence mechanismů, které by dokázaly překonat politické prŕíležitosti poskytované národními politickými jednotkami (srov. Tarrow 2000: 20). Proto podle Tarrowa sice dnes ,mohou občané cestovat jednodušeji než dříve [...], ale stále žijí ve státech a [...] mají př́ležitosti, sítě a dobře známé repertoáry [politického jednání] národních politických jednotek“" (Tarrow 2001a: 2-3).

Ani „hustá“ institucionální struktura EU nevytváří dostatečné podmínky pro překonání národních omezení politického jednání. To se Tarrow spolu s Imigem snaží dokázat na základě kvantitativní analýzy evropského protestu (Imig, Tarrow 2000, 2001a, 2001b). Podle jejích závě- 
rů tvoří naprostou většinu protestu v EU čistě domácí protest, tj. protest organizovaný domácími aktéry proti domácím cílům a využívající domácí repertoár protestního jednání. Tato forma protestu tvoři 95 procent všeho evropského protestu. To podle Imiga a Tarrowa koriguje entuziastická prohlášení o vzniku evropské občanské společnosti. Přesto však zbývajících pět procent protestu poukazuje na zatím ne př́liš výraznou, ale stále rostoucí tendenci k transnacionální koordinaci protestního jednání. Spolu s tím také roste počet a frekvence protestních událostí, které jsou provokovány evropskými politikami a institucemi. Pokud se však podíváme dovnitř této skupiny, závěry analýzy podle Imiga a Tarrowa potvrzují ta očekávání, která vycházejí z přesvědčení o přetrvávajícím významu národních politických př́ležitostí pro politické jednání. Téměř 83 procent protestu zaměřeného vůči EU ve vzorku protestních událostí, s nimiž Imig a Tarrow pracují, zachycuje protest domácích aktérů v domácím politickém prostředí, zatímco jen 17 procent tvořilo transnacionální protest (Imig, Tarrow 2001b: 36). I přesto, že autoři upozorňují, že výsledky jejich analýzy jsou založeny na použití nevyzkoušených metod a nejistých zdrojů, opakovaně zdůrazňují, že se cítí dostatečně jistí k tomu, aby mohli tvrdit, že ačkoli se evropští občané stále více organizují transnacionálně, ,stále se spoléhají především na domácí zdroje a př́ležitosti“ i tehdy, když se snaží prosadit požadavky proti evropským cílům (Tarrow 2001b: 237).

Výsledky tohoto výzkumu tak zpochybňují hypotézu o překotné europeanizaci politického jednání sociálních hnutí, nevládních organizací a zájmových skupin v těch zemích, které jsou členy EU. Zároveň je však třeba zdůraznit, že výsledky tohoto výzkumu se primárně týkají těch aktérů - at' už sociálních hnutí či zájmových skupin - kteří užívali protestních, tj. nekonvenčních, politických strategií. S jistou opatrností lze proto vyvodit následující: Ačkoli EU představuje vysoce institucionalizovaný prostor, který poskytuje nepřeberné množství př́ležitostí k prosazování zájmů, neznamená to automaticky, že tyto př́ležitosti budou využity. Politika se i v EU bude odehrávat také na úrovni jednotlivých národních států. To však z hlediska výše prezentované teorie MÚV nepředstavuje překvapující zjištění. I tato teorie postuluje význam národně státní úrovně, kterou však teoretizuje v kontextu dalších úrovní politického rozhodování.

Podle Tarrowa můžeme očekávat, že se EU rozvine do podoby jakési „složené pospolitosti“ (composite polity), která nebude připomínat uspořádání národních států, zároveň však ani nebude popsatelná nástroji, které využíváme k analýze mezinárodních organizací. Její uspořádání bude nepřehlednější než uspořádání moderního státu, bude však také hustěji institucionalizované než mezivládní organizace (Tarrow 2001b, srov. také Peterson 1995). Takové uspořádání se proto s výjimkou důrazu, který Tarrow klade na kolektivní mobilizaci neelitní části evropské populace, výrazně neliší od modelu, který navrhují teoretici MÚV (srov. také Hooghe, Marks 2001: 3). A to i přesto, že teorie MÚV prezentuje podle Tarrowa př́liš zjednodušený model struktury EU, v jejímž rámci se podle něj různé politické př́iležitosti nepřehledně křiží a překrývají nejen na různých úrovních rozhodování, ale také v různých teritoriálních a funkcionálních oblastech (srov. také Schmitter 2000). I podle Tarrowa tak EU představuje složitou institucionální strukturu, která různým typům aktérů poskytuje různé př́ležitosti pro jejich transnacionální aliance. Stejně jako i jiné mezinárodní organizace slouží také EU jako „korálový útes“, který umožňuje transnacionální mobilizaci (Tarrow 2001b: 246-247). Efekty tohoto působení popisuje Tarrow pomocí čtyř již zmíněných mechanismů - zprostředkování, certifikace, modelování a institucionálního přivlastnění (viz výše). 
Imig a Tarrow tak vlastně zpochybňují pouze tezi o „silné europeanizaci“, která bývá zpravidla ztotožňována s neofunkcionalistickým prŕstupem k evropské integraci. Pro neofunkcionalisty je integrace procesem taženým sebezájmem plurality politicko-ekonomických aktérů, kteří postupnou redefinicí svých loajalit na nadnárodní úrovni tlačí integrační proces vpřed. Je to pak právě sebezájem rozličných skupin v pluralitním prostředí západních demokracií, který by měl udržovat integrační proces v chodu. Protože je integrace chápána jako všem prospěšná hra (a positive-sum game), očekává se, že zainteresovaní aktéři postupně přesměrují své jednání z národní na nadnárodní úroveň a spolu s tím redefinují svou identitu a politickou loajalitu (Rosamond 2000: 66-68). Proto také neofunkcionalisté podtrhují důležitost nadnárodních evropských institucí, nebot' tyto instituce tvoří základní podmínku redefinice identit národních politických aktérů. Jejich jednání nutně motivuje posuny jak ve směru další integrace, tak také ve směru další europeanizace národních zájmových skupin.

Tato víra v progresivní europeanizaci domácí zájmové politiky však byla zpochybněna dávno před tím, než Imig a Tarrow doložili přetrvávající význam domácích politických arén pro aktivity západoevropských sociálních hnutí. Znamená to, že bychom k možnostem europeanizace aktivit domácích politických aktérů museli zaujmout zcela skeptický postoj? Jak ukazují výše uvedené př́spěvky k teorii politického jednání v EU (Marks, Hooghe, McAdam, Tarrow), zcela jistě ne. Fakt, že vstup ČR do EU nepovede automaticky k nahrazení domácího politického procesu evropským neznamená, že přistoupení zůstane bez jakékoli odezvy. I když k „silné“ europeanizaci zcela jistě nedojde, evropské instituce vytvoří dodatečnou úroveň politického rozhodování, která bude ovlivňovat také strategie původně českých politických subjektů. Tento vliv přitom nebude pouze jednostranný. Naopak - lze očekávat, že domácí političtí aktéři budou za určitých podmínek aktivně lobbovat na evropské úrovni, aby dosáhli svých domácích cílů.

Shrňme: Ani po přistoupení ČR do EU nelze očekávat, že by národní politický proces ztratil svou relevanci. Bude spíše vstupovat do vzájemné interakce s evropskými institucemi. Europeanizace zájmové politiky tak nebude spočívat v nahrazení domácích politických př́ležitostí, ale v jejich doplnění o další úroveň. Na průsečíku evropské úrovně a národního politického kontextu pak bude možné studovat způsoby jejich vzájemné interakce. Studium europeanizace by se proto mělo soustředit na konkrétní mody jejich vzájemného střetávání se. Závěrečná sekce přináší první verzi konceptuálního rámce pro studium způsobů interakce evropských institucí a domácích politických aktérů.

\section{Namísto závěru: Zpưsoby interakce}

Na základě dostupných zjištění lze předpokládat, že i po přistoupení ČR k EU budou české zájmové skupiny, nevládní organizace a sociální hnutí operovat v prostoru „mezi Prahou a Bruselem“. Jinými slovy řečeno, členství v EU nepovede k nahrazení národního politického procesu evropským. To však neznamená, že by se vstup do EU v aktivitách domácích politických aktérů nijak neprojevil. Již během přistupového procesu EU výrazným způsobem ovlivňovala dění v českém politickém poli (srov. Grabbe 2001, 2002). S přistoupením ČR lze očekávat, že se tento vliv nadále prohloubí. Jakým způsobem je možné interakci mezi institucemi EU a domácími politickými aktéry uchopit? Logicky představitelné možnosti předkládá následující tabulka. 


\section{Tabulka 1}

Zpưsoby interakce institucí EU a domácích politických aktérů

\begin{tabular}{|c|c|c|c|}
\hline \multicolumn{2}{|c|}{} & \multicolumn{2}{|c|}{ domácí politický aktér (na evropské úrovni) } \\
\cline { 2 - 4 } & aktivní & aktivní & pasivní \\
\hline \multirow{2}{*}{$\begin{array}{c}\text { evropské } \\
\text { instituce }\end{array}$} & pasivní & spolupráce/konflikt & $\begin{array}{c}\text { umocnění/zneschopnění politických } \\
\text { aktérů v domácím politickém poli }\end{array}$ \\
\cline { 2 - 4 } & transnacionální lobbování & indiference \\
\hline
\end{tabular}

Levý horní kvadrant představuje situaci, v níž se v určité politické oblasti spojí či naopak střetnou zájmy EU a domácích politických aktérů. V tomto př́padě lze očekávat bud' spolupráci, nebo otevřený konflikt. Obě strany rozvinou aktivní politické strategie bud' v totožném směru, anebo proti sobě. Pravý dolni kvadrant zase popisuje situaci, která je charakterizovaná nezájmem z obou stran. (Může se jednat o politickou oblast, která leží vně politických priorit EU a která není na evropské úrovni politizována ani žádným domácím politickým aktérem.) Tento kvadrant nepředstavuje teoreticky zajímavou kombinaci. Ty naopak představují zbývající dva kvadranty.

Kvadrant vpravo nahoře zachycuje situaci, kterou charakterizuje eminentní zájem ze strany EU, jež působí přímo na instituce členského státu. Zároveň je to oblast, která není charakterizována př́mým působením nestátního aktéra $\mathrm{z}$ daného státu na evropské instituce (domácí političtí aktéři bud' nejsou na evropské úrovni přítomni vůbec, nebo jsou pasivní). Domácí politické instituce v důsledku působení EU mění své uspořádání. Tím se pro některé domácí aktéry otevírají př́istupové body do politického systému, zatímco pro jiné se uzavírají. Výsledkem působení EU je v tomto př́padě umocnění některých aktérů a zneschopnění aktérů jiných na úrovni domácí politiky. V tomto př́ípadě tedy evropské struktury proměňují př́ležitosti pro politické jednání domácích politických aktérů. Umocnění mají na mysli např. Cowlesová a Risse, když rríkají, že „domácí aktéři, jejichž zájmy jsou europeanizací pozitivně ovlivněny a kteří mají schopnost a zdroje jednat v rámci domácího kontextu, mají sklon využít adaptačních tlaků ve svůj prospěch“ (Cowles, Risse 2001: 230).

Kvadrant vlevo dole popisuje situaci, která je charakterizována nezájmem ze strany EU, ale zároveň eminentním zájmem domácího politického aktéra ovlivnit situaci v dané politické oblasti. Ten proto rozvine aktivní politické strategie, aby strukturu evropských institucí ovlivnil ve prospěch jím prosazovaného cíle. V kontrastu $\mathrm{k}$ předchozí situaci, která je charakterizována působením evropských struktur na struktury domácí „shora“ (čímž dochází k proměně podmínek domácího politického boje), je tato situace charakterizována působením původně domácích politických aktérů na evropské instituce ,zdola“.

Tabulka nabízí první pokus o systematický pohled na škálu možných projevů europeanizace interakcí domácích politických aktérů. Všímá si různých zpo̊sobů, jimiž může tento proces probíhat, a zaměřuje se na vzájemný vztah domácích a evropských podmínek politického boje, které se budou v budoucnu vzájemně střetávat a ovlivňovat. Tento rámec zároveň upozorn̆uje na to, že europeanizace se nevyčerpává $\mathrm{v}$ jednostranném tlaku evropských institucí na národní politická prostředí (pro takový pohled viz Cowles, Caporaso, Risse 2001). Naopak - v některých př́padech to mohou být původně domácí političtí aktéři, kteří lobbováním EU sami při- 
spívají k tomu, aby EU vstupovala do domácích politických záležitostí (kvadrant vlevo dole). Tito (původně domácí) aktéři jsou $\mathrm{v}$ tomto př́padě primárními nositeli europeanizace, nebot' jsou to jejich intervence, které „vtahuji““ EU do konfliktů uvnitř národních politických jednotek. V tabulce představená teoretická očekávání však mohou být potvrzena (či vyvrácena) jen na základě budoucího empirického výzkumu.

\section{Poznámky}

Tato a následující sekce využívají a uvádějí do nového kontextu studia europeanizace některá zjištění, která autor již dř́ve publikoval. Srov. Císař 2002, 2003a, 2003b, 2003c.

2 Ke kritické diskusi podmínek, za nichž Moravcsikova teorie umožňuje určitou (velmi omezenou) roli transnacionálních aktérů, viz Cowles 2003: 104-105.

\section{Bibliografie}

Burstein, P. 1999. „Social Movements and Public Policy“. In M. Giugni, D. McAdam, Ch. Tilly (eds.) How Social Movements Matter. Minneapolis, London: University of Minnesota Press, s. 3-21.

Císař, O. 2002. „Teorie mezinárodních vztahů a evropská studia.“ Politologický časopis 10 (1): $50-67$.

Císař, O. 2003a. „Globální a lokální boje proti korupci: př́ípadová studie Transparency International.“ Politologický časopis 10 (3): 221-242.

Císař, O. 2003b. „The Transnationalisation of Political Conflict: Beyond Rationalism and Constructivism“. Journal of International Relations and Development 6 (1): 6-22.

Císař, O. 2003c. „Vzniká globální občanská společnost? Nestátní aktéři ve světové politice“. Mezinárodní vztahy 38 (4): 5-23.

Cowles, G. M. 2003. „Non-state Actors and False Dichotomies: Reviewing IR/IPE Approaches to European Integration“. Journal of European Public Policy 10 (1): 102-120.

Cowles, G. M., Risse, T. 2001. „Transforming Europe: Conclusions“. In M. G. Cowles, J. Caporaso, T. Risse (eds.) Transforming Europe. Europeanization and Domestic Change. Ithaca and London: Cornell University Press, s. 217-237.

Cowles, G. M., Caporaso, J., Risse, T. (eds.) 2001. Transforming Europe. Europeanization and Domestic Change. Ithaca and London: Cornell University Press.

Dürr, J., Marek, D., Šaradín, P. 2004. „Europeanizace české politické scény - politické strany a referendum o přistoupení k Evropské unii“. Mezinárodní vztahy 39 (1): 27-49.

Fiala, P., Schubert, K. 2000. Moderní analýza politiky. Brno: Barrister \& Principal.

Fiala, P., Pitrová, M. 2003. Evropská unie. Brno: CDK.

Galtung, F. 2000. „A Global Network to Curb Corruption: The Experience of Transparency International.“ In A. M. Florini (ed.) The Third Force: The Rise of Transnational Civil Society. Tokyo, Washington: Japan Center for International Exchange and Carnegie Endowment for International Peace, s. 17-47.

Grabbe, H. 2001. „How Does Europeanization Affect CEE Governance? Conditionality, Diffusion and Diversity“. Journal of European Public Policy 8 (6): 1013-1031.

Grabbe, H. 2002. „Europeanisation Goes East: Power and Uncertainty in the EU Accession Process". Paper for the ECPR Joint Sessions of Workshops. Turin, March 22-27 [online]. Dostupné z: http://www.essex.ac.uk/ecpr/jointsessions/turin/papers/ws4/grabbe.pdf. 
Hooghe, L., Marks, G. 2001. „Multi-Level Governance in the European Union“. In: L. Hooghe, G. Marks Multi-Level Governance and European Integration. Lanham, Boulder, New York, Oxford: Rowman and Littlefield, s. 1-32.

Imig, D., Tarrow, S. 2000. „Political Contention in a Europeanising Polity“. West European Politics 23 (4): 73-93.

Imig, D., Tarrow, S. 2001a. „Studying Contention in an Emerging Polity.“ In D. Imig, S. Tarrow (eds.) Contentious Europeans. Protest and Politics in an Emerging Polity. Lanham, Boulder, New York, Oxford: Rowman and Littlefield, s. 3-26.

Imig, D., Tarrow, S. 2001b. „Mapping the Europeanization of Contention: Evidence from a Quantitative Data Analysis“. In D. Imig, S. Tarrow (eds.) Contentious Europeans. Protest and Politics in an Emerging Polity. Lanham, Boulder, New York, Oxford: Rowman and Littlefield, s. 7-49.

Keck, M., Sikkink K. 1998. Activists Beyond Borders. Advocacy Networks in International Politics. Ithaca and London: Cornell University Press.

Keohane, R., Nye J. 2000. „Introduction“. In J. Nye, J. Donahue (eds.) Governance in a Globalizing World. Cambridge, Washington: Visions of Governance for the 21st Century, Brookings Institution Press, s. 1-41.

Königová, L. 2004. „Geneticky modifikované organizace? Twinning jako případ transnacionální interakce“. Mezinárodní vztahy 39 (1): 7-26.

Linden, R. (ed.) 2002. Norms and Nannies. The Impact of International Organizations on the Central and East European States. Lanham, Boulder, New York, Oxford: Rowman and Littlefield.

Marks, G. 1993. „Structural Policy and Multi-level governance in the European Community“. In A. Cafruny, G. Rosenthal (eds.) The State of the European Community II: The Maastricht Debates and Beyond. Boulder: Lynne Rienner, s. 391-410.

Marks, G., McAdam, D. 1999. „On the Relationship of Political Opportunities to the Form of Collective Action: the Case of the European Union.“ In D. della Porta, H. Kriesi, D. Rucht (eds.) Social Movements in a Globalizing World. New York: St. Martin's Press, s. 97-111.

Marks, G., Hooghe, L., Blank, K. 1996. „European Integration from the 1980s: State-centric v. Multi-level Governance“. Journal of Common Market Studies 34 (3): 341-378.

Meyer, D. 2003. „Political Opportunity and Nested Institutions“. Social Movement Studies 2(1): 17-35.

Moravcsik, A. 1991. „Negotiating the Single European Act: National Interests and Conventional Statecraft in the European Community“. International Organization 45 (1): 651-688.

Moravcsik, A. 1993. „Preferences and Power in the European Community: A Liberal Intergovernmentalist Approach“. Journal of Common Market Studies 31 (4): 473-524.

Moravcsik, A. 1998. The Choice for Europe: Social Purpose and State Power from Messina to Maastricht. Ithaca and London: Cornell University Press.

Peterson, J. 1995. „Decision-making in the European Union: Towards a Framework for Analysis“. Journal of European Public Policy 2 (1): 69-93.

Putnam, R. 1988. „Diplomacy and Domestic Politics: The Logic of Two Level Games“. International Organization 42 (3): 427-460.

Risse, T., Cowles G. M., Caporaso, J. 2001. „Europeanization and Domestic Change: Introduction.“ In M. G. Cowles, J. Caporaso, T. Risse (eds.) Transforming Europe. Europeanization and Domestic Change. Ithaca and London: Cornell University Press, s. 1-20. 
Risse, T., Ropp, S., Sikkink, K. (eds.) 1999. The Power of Human Rights: International Norms and Domestic Change. Cambridge: Cambridge University Press.

Risse-Kappen, T. (ed.) 1995. Bringing Transnational Relations Back In. Non-State Actors, Domestic Structures and International Institutions. Cambridge: Cambridge University Press.

Rosamond, B. 2000. Theories of European Integration. London: Macmillan.

Rosenau, J. 1992. „Governance, Order, and Change in World Politics“. In J. Rosenau, E. O. Czempiel (eds.) Governance without Government: Order and Change in World Politics, Cambridge: Cambridge University Press, s. 1-29.

Rosenau, J. 1998. „Governance and Democracy in a Globalizing World“. In D. Archibugi, D. Held, M. Köhler (eds.) Re-imagining Political Community. Studies in Cosmopolitan Democracy. Cambridge: Polity Press, s. 28-57.

Rosenau, J. 1999. „Toward an Ontology for Global Governance“. In M. Hewson, T. Sinclair (eds.) Approaches to Global Governance Theory. New York: State University of New York Press, s. 287-301.

Schimmelfennig, F. 2002. „Introduction: The Impact of International Organizations on the Central and East European States - Conceptual and Theoretical Issues“. In R. Linden (ed.) Norms and Nannies. The Impact of International Organizations on the Central and East European States. Lanham, Boulder, New York, Oxford: Rowman and Littlefield, s. 1-29.

Schmitter, P. C. 2000. How to Democratize the European Union ... and Why Bother? Lanham, Boulder, New York, Oxford: Rowman and Littlefield Publishers.

Tarrow, S. 1998. Power in Movement. Social Movements and Contentious Politics. Cambridge: Cambridge University Press.

Tarrow, S. 1999. „International Institutions and Contentious Politics: Does Internationalization Make Agents Freer or Weaker?". Presented to the Panel on „Coping with World Transitions “. American Sociological Association Annual Meeting. Chicago Illinois, August 6 [online]. Dostupné z: http://www.nd.edu/ dmyers/cbsm/vol2/stasa99.PDF

Tarrow, S. 2000. Transnational Contention. Badia Fiesolana, San Domenico: EUI Working Paper RSC 44.

Tarrow, S. 2001a. „Transnational Politics: Contention and Institutions in International Politics“. Annual Review of Political Science 4: 1-20.

Tarrow, S. 2001b. „Contentious Politics in a Composite Polity“. In D. Imig, S. Tarrow (eds.) Contentious Europeans. Protest and Politics in an Emerging Polity. Lanham, Boulder, New York, Oxford: Rowman and Littlefield, s. 233-251.

Tarrow, S. 2002. „From Lumping to Splitting: Specifying Globalization and Resistance“. In J. Smith, H. Johnson (eds.) Globalization and Resistance. Transnational Dimensions of Social Movements. Lanham, Boulder, New York, Oxford: Rowman and Littlefield, s. 229-249.

\section{Autor}

PhDr. Ing. Ondřej Císař, Ph.D. (1974) pracuje jako odborný asistent na katedře politologie FSS MU v Brně. Zabývá se politickou teorií, sociálními hnutími a dopady transnacionalizace na sociální hnutí a zájmové skupiny. Kontakt: cisar@fss.muni.cz 